\title{
STUDY ON WEIGHT OF THE POSTMORTEM PARATHYROID GLANDS IN A BANGLADESHI POPULATION
}

\author{
MAHBUB $\mathrm{S}^{1}$, NURUNNABI ASM ${ }^{2}$, ALIM A $^{3}$, AHMED R ${ }^{4}$, ARA $\mathrm{S}^{5}$
}

\begin{abstract}
:
Context: A cross-sectional descriptive type of study was designed to find out the difference in weight of the parathyroid glands of Bangladeshi people in relation to age and sex and to compare with the previous studies.

Methods: This study was done in the Department of Anatomy, Dhaka Medical College, Dhaka, from January to December 2008. The study was performed on 207 post mortem human parathyroid glands collected from 60 unclaimed dead bodies which were in the morgue under examination in the Department of Forensic Medicine, Dhaka Medical College, Dhaka. The samples were divided into three age-groups including group A (10-30 years), group B (31-60 years) \& group C (61-90 years) and the weight of the parathyroids were measured and recorded.

Results: The mean weight of the right superior parathyroid glands were $13.43 \pm 13.77 \mathrm{mg}$ in group $A, 13.86 \pm 19.15 \mathrm{mg}$ in group $B$ and $9.25 \pm 5.12 \mathrm{mg}$ in group $C$ in males and $16.00 \pm 6.69$ $\mathrm{mg}$ in group $A$ and $8.57 \pm 5.97 \mathrm{mg}$ in group $B$ in females respectively. The mean weight of the right inferior parathyroids were $17.78 \pm 13.94 \mathrm{mg}, 16.75 \pm 15.67 \mathrm{mg}$ and $23.00 \pm 11.53 \mathrm{mg}$ in group $A, B$ and $C$ respectively in males and $26.00 \pm 4.18 \mathrm{mg}$ in group $A$ and $15.20 \pm 4.32 \mathrm{mg}$ in group $B$ in females. The mean weight of the left superior parathyroid glands were $13.63 \pm 6.08$ $\mathrm{mg}$ in group $A, 10.58 \pm 7.57 \mathrm{mg}$ in group $B$ and $11.00 \pm 3.74 \mathrm{mg}$ in group $C$ in males and $16.20 \pm 7.89$ $\mathrm{mg}$ in group $A$ and $8.29 \pm 5.47 \mathrm{mg}$ in group $B$ in females respectively. The mean weight of the left inferior parathyroid gland was $26.11 \pm 24.29 \mathrm{mg}, 15.81 \pm 10.28 \mathrm{mg}$ and $25.25 \pm 25.28 \mathrm{mg}$ in group A, $B$ and $C$ respectively in males and $32.25 \pm 13.82 \mathrm{mg}$ in group $A$ and $13.29 \pm 5.41 \mathrm{mg}$ in group $B$ in females. No difference was found in the weight of superior parathyroid glands at right side between sexes and age groups excepting in superior and inferior parathyroid glands at left side between group $A \& B(p<0.05)$.
\end{abstract}

Key words: Parathyroid glands, weight of parathyroid.

J Dhaka Med Coll. 2013; 22(1) : 34-38.

\section{Introduction:}

The parathyroid glands are very essential for survival, as the hormones secreted by the parathyroids regulates circulating ionized calcium and maintains the internal milieu ${ }^{1}$. Parathyroid related clinical conditions such as parathyroid adenoma and hyperplasia are very common and cause hypercalcaemia ${ }^{2}$. Parathyroid adenoma or hyperplasia causes difference in size, shape and weight. Variation in weight signifies hypo/hyperfunctioning gland ${ }^{3}$. Moreover, it has been observed by various researchers that the dimensions of different organs in Bangladeshi population have got variations from those of the western population ${ }^{4}$. It is also observed by reviewing the literature and the texts that several works have been done on the parathyroids in foreign countries but proper attention has not been given to the normal morphological study in our country. Therefore, the study of the weight of this important organ has been designed to see whether there is any variation with age in Bangladeshi people as well as with those of the western studies.

1. Dr. Sabiha Mahbub, Associate Professor, Department of Anatomy, City Medical College, Gazipur.

2. Dr. Abu Sadat Mohammad Nurunnabi, Lecturer, Department of Anatomy, Dhaka Medical College, Dhaka.

3. Dr. Abdul Alim, Assistant Professor, Department of Anatomy, Mymensingh Medical College, Mymensingh.

4. Dr. Rukshana Ahmed, Assistant Professor, Department of Anatomy, Dhaka Medical College, Dhaka.

5. Dr. Shamim Ara, Professor and Head, Department of Anatomy, Dhaka Medical College, Dhaka.

Correspondence : Dr. Sabiha Mahbub, Associate Professor, Department of Anatomy, City Medical College, Gazipur. 


\section{Methods:}

The present study was performed on post mortem parathyroid glands of 60 Bangladeshi people of both sexes in different age groups ranging from 15 to 75 years. Total 207 parathyroid glands were taken from those cadavers. The study was done from January to December 2008. The human parathyroid glands were collected from unclaimed dead bodies that were under examination in the Department of Forensic Medicine of Dhaka Medical College, Dhaka. After legal formalities and permission from Department of Forensic Medicine, the samples were collected within 24 hours of death without any sign of putrefaction. All the samples were collected from medico-legal cases. During collection appropriate age, sex, and cause of death were noted from morgue's record book. The samples were brought to the Department of Anatomy, Dhaka Medical College, Dhaka. The samples were tagged immediately, which was bearing a code number for subsequent identification. Soon after collection each sample was gently washed in tap water on a dissection tray. Blood and blood clots were removed as far as possible. Then the samples were fixed in $10 \%$ formol saline solution.

\section{Grouping of the Sample}

For convenience of description in relation to age the collected samples were divided into three groups (according to Panijan et al. ${ }^{5}$ ) (Table-I).

Table-I

Grouping of the sample in relation to age

\begin{tabular}{lccc}
\hline Group & $\begin{array}{c}\text { Age limit } \\
\text { in years }\end{array}$ & $\begin{array}{c}\text { Number } \\
\text { of person }\end{array}$ & $\begin{array}{c}\text { Number of collected } \\
\text { parathyroid glands }\end{array}$ \\
\hline A & $10-30$ & 27 & 93 \\
B & $31-60$ & 28 & 98 \\
C & $61-90$ & 5 & 16 \\
\hline
\end{tabular}

\section{Procedure of collection of sample}

From each cadaver the parathyroid glands were collected by "Block Dissection", using the following steps:

During postmortem examination, neck, thoracic cavity and the abdominal cavity were routinely exposed by midline incision from chin to symphysis pubis. In the neck region, incision was given carefully to avoid any damage to the isthmus or any part of the thyroid gland. The skin, along with the platysma was retracted laterally. The sternocleidomastoid muscles were cut in the middle and retracted laterally for the exposure of the thyroid gland. Then the sternocleidomastoid and the superior belly of omohyoid were displaced laterally. Cutting through the sternothyroid near its lower end and turning it upwards to the thyroid cartilage were done. The fascia from the lobes of the thyroid gland was removed, exposing its arteries and veins. Searching for parathyroid glands was done all through the posterior surface of the thyroid gland. Small yellowishbrown ductless parathyroid glands were embedded either in the posterior surface of the capsule of the thyroid gland or outside the capsule. Then the parathyroid glands were separated and collected ${ }^{6}$.

Then each parathyroid gland was taken and its outer surface was dried with blotting paper and it was weighed by means of a digital balance (SCIENTECH ZSA 210, made in USA) in grams. The comparison between right and left side was done by unpaired Student's ' $t$ ' test and the comparison between different groups was done by One-way ANOVA. All the statistical analyses were done by using the SPSS 11.0 version.

This research work was approved by the Ethical Review Committee of Dhaka Medical College, Dhaka.

\section{Results:}

Right superior parathyroid glands: In the present study, the mean weight of the parathyroid glands were $13.43 \pm 13.77 \mathrm{mg}$ in group A (10-30 years), $13.86 \pm 19.15 \mathrm{mg}$ in group B (31-60 years) and $9.25 \pm 5.12 \mathrm{mg}$ in group $\mathrm{C}$ (61-90 years) in males (Table-IIa). The mean weight of the parathyroid glands were $16.00 \pm 6.69 \mathrm{mg}$ in group $A$ and $8.57 \pm 5.97 \mathrm{mg}$ in group $B$ in females (Table-IIa). No difference was found in the weight of superior parathyroid glands at right side between sexes (Table-IIa) and age groups (Table-III). 
Table-IIa

Weight of right parathyroid glands in male and female of different age groups

\begin{tabular}{|c|c|c|c|c|}
\hline \multicolumn{5}{|c|}{ Weight of parathyroid glands $(\mathrm{mg})$ right side } \\
\hline $\begin{array}{l}\text { Age group/ } \\
\text { Sex }\end{array}$ & $\begin{array}{c}\text { Superior } \\
\text { Mean } \pm \text { SD }\end{array}$ & $\mathrm{P}$ value & $\begin{array}{c}\text { Inferior } \\
\text { Mean } \pm \text { SD }\end{array}$ & $\mathrm{P}$ value \\
\hline \multicolumn{5}{|l|}{ Group A } \\
\hline Male & $\begin{array}{c}13.43 \pm 13.77 \\
(\mathrm{n}=21)\end{array}$ & & $\begin{array}{c}17.78 \pm 13.94 \\
(\mathrm{n}=18)\end{array}$ & \\
\hline Female & $\begin{array}{c}16.00 \pm 6.69 \\
(n=6)\end{array}$ & $>0.50^{\mathrm{ns}}$ & $\begin{array}{c}26.00 \pm 4.18 \\
(n=5)\end{array}$ & $>0.10^{\text {ns }}$ \\
\hline $\begin{array}{l}\text { Group B } \\
\text { Male }\end{array}$ & $\begin{array}{c}13.86 \pm 19.15 \\
(n=21)\end{array}$ & & $\begin{array}{c}16.75 \pm 15.67 \\
(n=16)\end{array}$ & \\
\hline Female & $\begin{array}{c}8.57 \pm 5.97 \\
(\mathrm{n}=7)\end{array}$ & $>0.10^{\mathrm{ns}}$ & $\begin{array}{c}15.20 \pm 4.32 \\
(\mathrm{n}=5)\end{array}$ & $>0.50^{\mathrm{ns}}$ \\
\hline Group C & & & & \\
\hline Male & $\begin{array}{c}9.25 \pm 5.12 \\
(n=4)\end{array}$ & & $\begin{array}{c}23.00 \pm 11.53 \\
(n=3)\end{array}$ & \\
\hline Female & $\begin{array}{l}00.00 \\
(n=0)\end{array}$ & & $\begin{array}{l}00.00 \\
(n=0)\end{array}$ & \\
\hline
\end{tabular}

Comparison between sex done by unpaired Student's ' $\mathrm{t}$ ' test, ns = not significant.

Group A : Age 10-30 years

Group B : Age 31-60 years

Group C : Age 61-90 years

Table-IIb

Weight of left parathyroid glands in male and female of different age groups

\begin{tabular}{|c|c|c|c|c|}
\hline \multirow[b]{2}{*}{$\begin{array}{l}\text { Age group/ } \\
\text { Sex }\end{array}$} & \multicolumn{3}{|c|}{ Weight of parathyroid glands (mg) left side } & \multirow[b]{2}{*}{$P$ value } \\
\hline & $\begin{array}{l}\text { Superior } \\
\text { Mean } \pm \text { SD }\end{array}$ & $P$ value & $\begin{array}{l}\text { Inferior } \\
\text { Mean } \pm \text { SD }\end{array}$ & \\
\hline \multicolumn{5}{|l|}{ Group A } \\
\hline Male & $\begin{array}{c}13.63 \pm 6.08 \\
(n=16)\end{array}$ & \multirow[b]{2}{*}{$>0.10^{\mathrm{ns}}$} & $\begin{array}{c}26.11 \pm 24.29 \\
(\mathrm{n}=18)\end{array}$ & \multirow[b]{2}{*}{$>0.50^{\mathrm{ns}}$} \\
\hline Female & $\begin{array}{c}16.20 \pm 7.89 \\
(\mathrm{n}=5)\end{array}$ & & $\begin{array}{c}32.25 \pm 13.82 \\
(n=4)\end{array}$ & \\
\hline \multicolumn{5}{|l|}{ Group B } \\
\hline Male & $\begin{array}{c}10.58 \pm 7.57 \\
(n=19)\end{array}$ & \multirow[b]{2}{*}{$>0.10^{\text {ns }}$} & $\begin{array}{c}15.81 \pm 10.28 \\
(n=16)\end{array}$ & \multirow[b]{2}{*}{$>0.10^{\mathrm{ns}}$} \\
\hline Female & $\begin{array}{c}8.29 \pm 5.47 \\
(\mathrm{n}=7)\end{array}$ & & $\begin{array}{c}13.29 \pm 5.41 \\
(\mathrm{n}=7)\end{array}$ & \\
\hline Group C & & & & \\
\hline Male & $\begin{array}{c}11.00 \pm 3.74 \\
(n=5)\end{array}$ & & $\begin{array}{c}25.25 \pm 25.28 \\
(n=4)\end{array}$ & \\
\hline Female & $\begin{array}{c}00 \\
(n=0)\end{array}$ & & $\begin{array}{c}00 \\
(\mathrm{n}=0)\end{array}$ & \\
\hline
\end{tabular}

Comparison between sex done by unpaired Student's ' $\mathrm{t}$ ' test, ns = not significant.

Group A : Age 10-30 years

Group B : Age 31-60 years

Group C : Age 61-90 years 
Right inferior parathyroid glands: The mean weight of the parathyroids were $17.78 \pm 13.94$ $\mathrm{mg}$ in group A, $16.75 \pm 15.67 \mathrm{mg}$ in group B and $23.00 \pm 11.53 \mathrm{mg}$ in group $\mathrm{C}$ in males (TableIIa). The mean weight of the parathyroid glands were $26.00 \pm 4.18 \mathrm{mg}$ in group A and 15.20 \pm 4.32 $\mathrm{mg}$ in group $\mathrm{B}$ in females (Table-IIa). No difference was found in the weight of inferior parathyroid glands at right side between sexes (Table-IIa) and age groups (Table-III).

Left superior parathyroid glands: In the present study, the mean weight of the parathyroid glands were $13.63 \pm 6.08 \mathrm{mg}$ in group A, $10.58 \pm 7.57 \mathrm{mg}$ in group B and $11.00 \pm 3.74$ $\mathrm{mg}$ in group $\mathrm{C}$ in males (Table-IIb). The mean weight of the parathyroid was $16.20 \pm 7.89 \mathrm{mg}$ in group A and $8.29 \pm 5.47 \mathrm{mg}$ in group B in females (Table-IIb). No difference was found in the weight of superior parathyroid glands at left side between sexes (Table-IIb) and age groups (Table-III).

Left inferior parathyroid glands: The mean weight of the parathyroid gland was $26.11 \pm 24.29$ $\mathrm{mg}, 15.81 \pm 10.28 \mathrm{mg}$ and $25.25 \pm 25.28 \mathrm{mg}$ in group $\mathrm{A}, \mathrm{B}$ and $\mathrm{C}$ respectively in males (TableIIb). The mean weight of the parathyroid was $32.25 \pm 13.82 \mathrm{mg}$ in group A and $13.29 \pm 5.41 \mathrm{mg}$ in group B in females (Table-IIb). No difference was found in the weight of inferior parathyroid glands at left side between sexes (Table-IIb). However, the difference in mean weight of superior and inferior parathyroid glands at left side was only found between group A \& B $(\mathrm{p}<0.05)$ (Table-III).

Table-III

Weight of right and left parathyroid glands in different age groups

\begin{tabular}{ccccccc}
\hline \multicolumn{5}{c}{ Weight of parathyroid glands $(\mathrm{mg})$} \\
\cline { 2 - 6 } Age & Superior & $\begin{array}{c}\text { Right side } \\
\text { Inferior }\end{array}$ & & Superior & $\begin{array}{c}\text { Left side } \\
\text { Inferior }\end{array}$ & \\
group & Mean \pm SD & Mean \pm SD & P value & Mean \pm SD & Mean \pm SD & P value \\
\hline A & $14.00 \pm 12.48$ & $19.57 \pm 12.86$ & $>0.10^{\text {ns }}$ & $14.24 \pm 6.43$ & $27.23 \pm 22.60$ & $<0.05^{*}$ \\
& $(\mathrm{n}=27)$ & $(\mathrm{n}=23)$ & & $(\mathrm{n}=21)$ & $(\mathrm{n}=22)$ & \\
B & $12.54 \pm 16.88$ & $16.38 \pm 13.72$ & $>0.10^{\mathrm{ns}}$ & $9.96 \pm 7.04$ & $15.04 \pm 9.03$ & $<0.05^{*}$ \\
& $(\mathrm{n}=28)$ & $(\mathrm{n}=21)$ & & $(\mathrm{n}=26)$ & $(\mathrm{n}=23)$ & \\
C & $9.25 \pm 5.12$ & $23.00 \pm 11.53$ & $>0.05^{\mathrm{ns}}$ & $11.00 \pm 3.74$ & $25.25 \pm 25.28$ & $>0.10^{\mathrm{ns}}$ \\
& $(\mathrm{n}=4)$ & $(\mathrm{n}=3)$ & & $(\mathrm{n}=5)$ & $(\mathrm{n}=4)$ & \\
& $P$ value & $P$ value & Pvalue & $P$ value & & \\
A vs B & $>0.50^{\mathrm{ns}}$ & $>0.10^{\mathrm{ns}}$ & $<0.05^{*}$ & $<0.05^{*}$ & & \\
A vs C & $>0.50^{\mathrm{ns}}$ & $>0.50^{\mathrm{ns}}$ & $>0.10^{\mathrm{ns}}$ & $>0.10^{\mathrm{ns}}$ & & \\
B vs C & $>0.50^{\mathrm{ns}}$ & $>0.10^{\mathrm{ns}}$ & $>0.50^{\mathrm{ns}}$ & $>0.50^{\mathrm{ns}}$ & & \\
\hline
\end{tabular}

Comparison between weight of superior and inferior parathyroid glands of right and left side done by unpaired Student's ' $t$ ' test, and comparison between groups done by One way ANOVA (PostHoc), ns $=$ not significant, ${ }^{*}=$ significant.

Group A : Age $10-30$ years
Group B : Age $31-60$ years
Group C : Age $61-90$ years 


\section{Discussion:}

Gilmour and Martin (1937) ${ }^{7}$ examined the weights of parathyroid glands in 428 autopsy cases. He stated that each normal parathyroid gland weighed of $29.4 \mathrm{mg}$ for male and $32.8 \mathrm{mg}$ for female. Wang $(1976)^{8}$ studied the weight of 645 normal glands from 160 cadavers. He reported that the average weight of parathyroid gland ranges between 35 and $40 \mathrm{mg}$. The smallest parathyroid weighed $10 \mathrm{mg}$ and the largest, $78 \mathrm{mg}$. It varied somewhat with age and sex, being heavier in the man and in persons between 20 and 30 years of age, and lighter in the woman and in those between 70 and 80 . The study done by Dufour and Wilkerson (1983) ${ }^{9}$ described that the average weight of the gland was $29.5 \mathrm{mg}$ in white and $46.5 \mathrm{mg}$ in black people. According to GhandurMnaymneh et al. (1986) ${ }^{10}$, the mean weight of each parathyroid gland is $42.6 \pm 20.3 \mathrm{mg}$, with a range of 22-103 $\mathrm{mg}$. The weight of the parathyroid gland described by Yao et al. $(2004)^{11}$ ranges from $18-161 \mathrm{mg}$ and their mean weight was $62.4 \pm 31.6 \mathrm{mg}$, as they collected 34 intact normal glands during surgical operation for parathyroid adenomas. According to Berkovitz (2005) ${ }^{12}$, each parathyroid gland weighs about $50 \mathrm{mg}$. Doherty $(2011)^{13}$ stated that each normal parathyroid gland weighed between 30 and $50 \mathrm{mg}$. and the weight of the lower parathyroid gland is usually more than the upper one. The results of the present study are more or less same in comparison to the previous studies.

\section{Acknowledgement:}

We express our heartfelt gratitude to the authority of Health, Nutrition and Population sector Programme (HNPSP) of Directorate General of Health Services (DGHS) of Government of the People's Republic of Bangladesh and Dhaka Medical College for the research grant.

\section{References:}

1. Rosai J. Rosai and Ackerman's surgical pathology. Vol.1. 9 ${ }^{\text {th }}$ ed. New Delhi: Elsevier Mosby; 2004. p. 595-610.

2. Kumar V, Abbas AK, Fausto N. eds. Robbins and Cotran pathologic basis of disease. $7^{\text {th }}$ ed. New Delhi: Saunders; 2004. p.1183-9.

3. Damjanov I, Linder J. eds. Anderson's pathology. $10^{\text {th }}$ ed. St. Louis: Mosby; 1996. p.1980-2008.

4. Enayetullah M. Gross and histomorphological study of the thyroid and parathyroid glands in Bangladeshi people (M.Phil.Thesis). Dhaka: IPGMR, University of Dhaka; 1996. p.17.

5. Panijan RP, Grbesa D, Mederal P, Jezek D, Cavcic A, Gorsic I. Do parathyroid glands from individuals of different age and gender contain lymph vessels?. Coll Antropol 2006; 30(2): 369-73.

6. Romanes GJ. ed. Cunningham's manual of practical anatomy. Vol.3. $15^{\text {th }}$ ed. New York: Oxford University Press; 2005. p. 64-8.

7. Gilmour JR, Martin WJ. The weight of the parathyroid gland. J Pathol Bacteriol 1937; 44: 431-62.

8. Wang $\mathrm{C}$. The anatomic basis of parathyroid surgery. Ann Surg 1976; 183(3): 271-5.

9. Dufour D, Wilkerson SY. Factors related to parathyroid weight in normal persons. Arch Pathol Lab Med 1983; 107: 167-72.

10. Ghandur-Mnaymneh L, Cassady J, Hajianpour MA, Paz J, Reiss E. The parathyroid gland in health and disease. Am J Pathol 1986; 125(2): 292-9.

11. Yao K, Singer FR, Roth SI, Sassoon A, Ye C, Giuliano AE. Weight of normal parathyroid glands in patients with parathyroid adenomas. J Clin Endocrinol Metab 2004; 89(7): 3208-13.

12. Berkovitz BK. ed. Neck and upper aero-digestive tract. In: Standring S, Ellis H, Healy JC, Johnson D, Williams A, Collins P, et al. eds. Gray's anatomy: the anatomical basis of clinical practice. $39^{\text {th }}$ ed. London: Elsevier Churchill Livingstone; 2005.

13. Doherty GM. Parathyroid gland. In: Greenfield LJ, Mulholland MW, Lillemoe KD, Doherty GM, Maier RV, Simeone DM, Upchurch GR. eds. Greenfield's surgery: scientific principles and practice. $5^{\text {th }}$ ed. Philadelphia: Lippincott Williams \& Wilkins; 2011. 